Article

\title{
Evaluation of Fermentative Hydrogen Production from Single and Mixed Fruit Wastes
}

\section{Julius Akinbomi * and Mohammad J. Taherzadeh}

Swedish Centre for Resource Recovery, University of Borås, 50190 Borås, Sweden;

E-Mail: Mohammad.Taherzadeh@hb.se

* Author to whom correspondence should be addressed; E-Mail: Julius.Akinbomi@hb.se;

Tel.: +46-334-354-585.

Academic Editor: Calliope Panoutsou

Received: 5 February 2015 / Accepted: 5 May 2015 / Published: 12 May 2015

\begin{abstract}
The economic viability of employing dark fermentative hydrogen from whole fruit wastes as a green alternative to fossil fuels is limited by low hydrogen yield due to the inhibitory effect of some metabolites in the fermentation medium. In exploring means of increasing hydrogen production from fruit wastes, including orange, apple, banana, grape and melon, the present study assessed the hydrogen production potential of singly-fermented fruits as compared to the fermentation of mixed fruits. The fruit feedstock was subjected to varying hydraulic retention times (HRTs) in a continuous fermentation process at $55{ }^{\circ} \mathrm{C}$ for 47 days. The weight distributions of the first, second and third fruit mixtures were $70 \%$, $50 \%$ and $20 \%$ orange share, respectively, while the residual weight was shared equally by the other fruits. The results indicated that there was an improvement in cumulative hydrogen yield from all of the feedstock when the HRT was five days. Based on the results obtained, apple as a single fruit and a fruit mixture with $20 \%$ orange share have the most improved cumulative hydrogen yields of 504 (29.5\% of theoretical yield) and $513 \mathrm{~mL} / \mathrm{g}$ volatile solid (VS) (30\% of theoretical yield), respectively, when compared to other fruits.
\end{abstract}

Keywords: whole fruit wastes; singly-digested fruits; mixing proportion; biohydrogen; retention time; significant effect 


\section{Introduction}

The quest for renewable, efficient and environmentally-friendly alternative energy sources to fossil fuels has stimulated intense research studies on fermentative hydrogen $\left(\mathrm{H}_{2}\right)$ production from biomass. Among other renewable energy sources (solar, hydro-power, wind and geothermal), fermentative $\mathrm{H}_{2}$ production has received remarkable interest due to its striking properties, including having very high energy content per unit mass and being a clean energy carrier, as it forms only water vapor during combustion [1-3]. Fermentative $\mathrm{H}_{2}$ production can facilitate the quick transition of the hydrocarbon-based economy to a hydrogen-based economy, especially in the transport sector. Fuel cell electric vehicles powered by fermentative $\mathrm{H}_{2}$ are zero emission vehicles that could be used as green energy technology to tackle the challenge of depleted fossil fuel reserves and pollution associated with conventional transport fuels. Furthermore, the considerable attention on fermentative $\mathrm{H}_{2}$ is also due to the reliability of the continuous supply of feedstock, which is inevitably generated from daily human and animal activities. Among the feedstock available for $\mathrm{H}_{2}$ production, fruit wastes have relative great economic and environmental potential due to the large quantities of wastes generated from fruit consumption and industrial processing $(10 \%-65 \%$ of raw fruit) [4]. The application of fruit wastes as feedstock for $\mathrm{H}_{2}$ production is an eco-friendly process, since littered fruit wastes could constitute a health nuisance to people and the environment. Meanwhile, due to low $\mathrm{H}_{2}$ yield from the fermentation process, most of the hydrogen currently used in various industrial applications is obtained from non-green sources, including steam reforming of natural gas, water electrolysis and coal gasification [5-7]. Low $\mathrm{H}_{2}$ yield during the fermentation process is attributed to, among other factors, the natural tendency of the fermentation process to be optimized to produce cell biomass instead of $\mathrm{H}_{2}$. In a dark fermentation process, $12 \mathrm{~mol} \mathrm{H} / \mathrm{mol}$ glucose could be theoretically obtained from complete conversion of glucose to $\mathrm{H}_{2}$ and carbon dioxide (Equation (1)), but the reaction is thermodynamically impossible due to the production of a large quantity of by-products (volatile fatty acids (VFAs), alcohols and lactate) associated with $\mathrm{H}_{2}$ production. The thermodynamic constraints make the maximum attainable $\mathrm{H}_{2}$ yields to be 4 and $2 \mathrm{~mol} / \mathrm{mol}$ glucose if the associated by-products are acetate and butyrate, respectively (Equations (2) and (3)) [8,9]:

$$
\begin{gathered}
\mathrm{C}_{6} \mathrm{H}_{12} \mathrm{O}_{6}+6 \mathrm{H}_{2} \mathrm{O} \rightarrow 12 \mathrm{H}_{2}+6 \mathrm{CO}_{2}\left(\Delta \mathrm{G}^{\circ}=+3.2 \mathrm{~kJ}\right) \\
\mathrm{C}_{6} \mathrm{H}_{12} \mathrm{O}_{6}+2 \mathrm{H}_{2} \mathrm{O} \rightarrow 4 \mathrm{H}_{2}+2 \mathrm{CO}_{2}+2 \mathrm{CH}_{3} \mathrm{COOH}(\text { acetate })\left(\Delta \mathrm{G}^{\circ}=-206 \mathrm{~kJ}\right) \\
\mathrm{C}_{6} \mathrm{H}_{12} \mathrm{O}_{6} \rightarrow 2 \mathrm{H}_{2}+2 \mathrm{CO}_{2}+\mathrm{CH}_{3} \mathrm{CH}_{2} \mathrm{CH}_{2} \mathrm{COOH}(\text { butyrate })\left(\Delta \mathrm{G}^{\circ}=-254 \mathrm{~kJ}\right)
\end{gathered}
$$

The low $\mathrm{H}_{2}$ from the fermentation process could also be attributed to feedstock inhibition including the antimicrobial inhibition of flavor compounds in fruit. During the ripening process, fruits usually produce flavor compounds (esters, alcohols, aldehydes, ketones, lactones and terpenoids), which are used as natural defense mechanisms in plants against microbial invasion (Table 1) [10-24]. Although the amount of fruit flavors in fruits is not high (usually $0.001 \%-0.01 \%$ of the fruit's fresh weight), the antimicrobial effect of the flavor compounds cannot be ignored. The positive effect of the flavor compounds in fruit is responsible for fruit freshness and the long shelf life of fruits, while a negative effect has been observed to be responsible for the inhibition of bacterial activities during the fermentation process. For instance, D-limonene, which is a citrus flavor belonging to a class of terpenoids, was found 
to have an antimicrobial effect at a very low concentration of $0.01 \% \mathrm{w} / \mathrm{v}[11,25-27]$ and to cause the failure of the anaerobic digestion process, even at a very low concentration of $400 \mu \mathrm{L} / \mathrm{L}$ [26]. As a result, some strategic approaches have been developed to mitigate the antimicrobial effect of limonene and, consequently, to improve bioenergy production during anaerobic digestion. In a study by Youngsukkasem et al. [28], an encapsulated membrane was effectively used to reduce the inhibitory effect of D-limonene on the fermentative bacteria. Membrane-encased bacteria were observed to tolerate up to $3 \%$ limonene in the synthetic medium with consequent higher methane production than free cells. Wikandiri et al. [29] also developed a membrane bioreactor that could tolerate between 5 and $10 \mathrm{~g} / \mathrm{L}$ of limonene in the feedstock for biomethane generation. Similarly, various techniques, including feedstock and inoculum pretreatment, optimal inoculum-to-substrate ratio, gas sparging, bioreactor design and a two-stage fermentation system, among others, have been employed for improving the recovery efficiency of fermentative $\mathrm{H}_{2}$ from food wastes, especially fruit wastes [30-33].

Table 1. Fruit flavors in some fruits.

\begin{tabular}{|c|c|c|c|}
\hline \multirow[t]{2}{*}{ Fruit } & \multicolumn{2}{|l|}{ Fruit Flavor } & \multirow[t]{2}{*}{ References } \\
\hline & Flavor compound & Flavor group & \\
\hline \multirow{3}{*}{ Orange } & Hexanal and nonanal & Aldehydes & {$[10]$} \\
\hline & Octanol, 3-methyl butanol & Alcohols & {$[10,23]$} \\
\hline & $\alpha$-pinene, car-3-ene, myrcene and limonene & Terpenoid & {$[10,11]$} \\
\hline \multirow{4}{*}{ Banana } & Pentanone, heptanone, undecanone & Ketones & {$[12,13]$} \\
\hline & Butanal, hexanal and E-2-hexanal & Aldehydes & {$[12,13]$} \\
\hline & 1-butanol, 2-pentanol, 3-methyl-1-butanol, 1-hexanol and eugenol & Alcohol & {$[12,13]$} \\
\hline & $\begin{array}{l}\text { Ethyl acetate, butyl acetate, 2-methyl propyl acetate, hexyl acetate, } \\
\text { hexyl butanoate and butyl butanoate }\end{array}$ & Esters & {$[12,13]$} \\
\hline \multirow{5}{*}{ Apple } & n-Hexanal, E-2-hexenal, nonanal, acetaldehyde & Aldehydes & {$[10,14]$} \\
\hline & Hexanol and butanol & Alcohols & {$[14]$} \\
\hline & Car-3-ene & Terpenoid & {$[10]$} \\
\hline & Ethyl butanoate, ethyl -2-methylbutanoate, hexyl acetate, etc. & Ester & {$[14,15,23]$} \\
\hline & Epicatechin & Polyphenol & {$[16,17]$} \\
\hline \multirow{4}{*}{ Grape } & Hexanal & Aldehyde & {$[10]$} \\
\hline & Octanol and hexanol & Alcohols & {$[14,18]$} \\
\hline & Hexyl acetate, ethyl acetate and ethyl hexanoate & Esters & {$[10,18,19]$} \\
\hline & Quercetin and epicatechin & Polyphenol & {$[16]$} \\
\hline \multirow{2}{*}{ Melon } & Nonanal, benzaldehyde and E-2-nonenal & Aldehydes & {$[20-22]$} \\
\hline & Ethyl 2-methyl propyl acetate and 2-methyl butyl acetate & Esters & {$[20-22]$} \\
\hline
\end{tabular}

Meanwhile, in most research work on fermentative $\mathrm{H}_{2}$ from fruit wastes, fruit peels are often used as feedstock, since they are discarded during consumption and industrial processing. However, research should also be focused on the application of whole fruit wastes as feedstock, since large quantities of whole fruit wastes are generated during harvest, transportation and storage, due to microbial or pest attack. The objective of this study was therefore to investigate the effect of combined varying hydraulic retention time (HRT) and fruit mixing ratio on fermentative $\mathrm{H}_{2}$ yield from whole fruit wastes in order to have an idea of how to manage whole fruit wastes feedstock for optimal fermentative hydrogen production. The potential of fruit biodegradability and fermentative hydrogen production could be enhanced or lessened by the characteristics of fruit mixtures (nutrient composition, carbon to nitrogen 
ratio, toxicity) obtained when two or more fruits were combined. Besides nutrient composition, the inherent antimicrobial flavor compounds in fruits could also be a decisive factor in the overall effect. Unlike single fruit waste, mixed fruit wastes have the advantage of mutual interaction between various fruits in the fruit mixture, which might result in varying degrees of inhibitory and enhanced effects due to factors, such as additive (a combined effect equal to the sum of the individual effects), synergistic (a combined effect greater than the sum of the individual effects) and antagonistic effects (a combined effect less than the individual effects).

\section{Results and Discussion}

The performance of the fermentative $\mathrm{H}_{2}$ production process from the whole fruit wastes of orange, banana, apple, grape and melon was evaluated by measuring the hydrogen yield and volatile fatty acid (VFA) productions. The hydraulic retention times (HRTs) were reduced as the organic loading rates (OLR) were subsequently increased in the experiments. Although the mass of the different fruit wastes fed to the reactors were equal, their OLRs were not the same, because of different percentages of volatile solids in each fruit waste. The fermentation process was in three phases, Phase 1, 2 and 3, which corresponded to HRT of 8.6, 5 and 3 days, respectively. The continuous stirred tank reactors (CSTRs) were started up with an initial HRT of 8.6 days, which was the first phase of the fermentation process spanning a period of 15 days. During the second phase, which covered the period between the 16th and 30th days, the HRT was decreased from 8.6 down to five days. The HRT was furthered reduced to three days during the third phase, which spanned the period between the 31 st and 47 th days.

\subsection{Hydrogen Production Yields from Singly-Digested Fruits}

The hydrogen production from the singly-digested fruits was monitored throughout the three phases of the 47-day period. During the first phase (HRT of 8.6 days), hydrogen yields from the fermentation of individual fruits increased, except the yield from grape, which decreased sharply (Figure 1) due to the decrease in $\mathrm{pH}$ values. The highest (493 $\mathrm{mL} / \mathrm{gVS}_{\text {added; }} \mathrm{VS}$, volatile solid) and lowest $\left(216 \mathrm{~mL} / \mathrm{gVS}_{\text {added}}\right)$ average hydrogen yields during the first phase were obtained from apple and melon, respectively. The hydrogen yields of all of the fruits increased during the second phase (HRT of five days), with apple and melon still producing the highest and lowest average hydrogen yields of 635 and $352 \mathrm{~mL} / \mathrm{gVS}_{\text {added, }}$, respectively. The average hydrogen yields during the third phase (HRT of three days), however, decreased with apple and grape, producing the highest and lowest yields of 440 and $182 \mathrm{~mL} / \mathrm{gVS}$, respectively. 


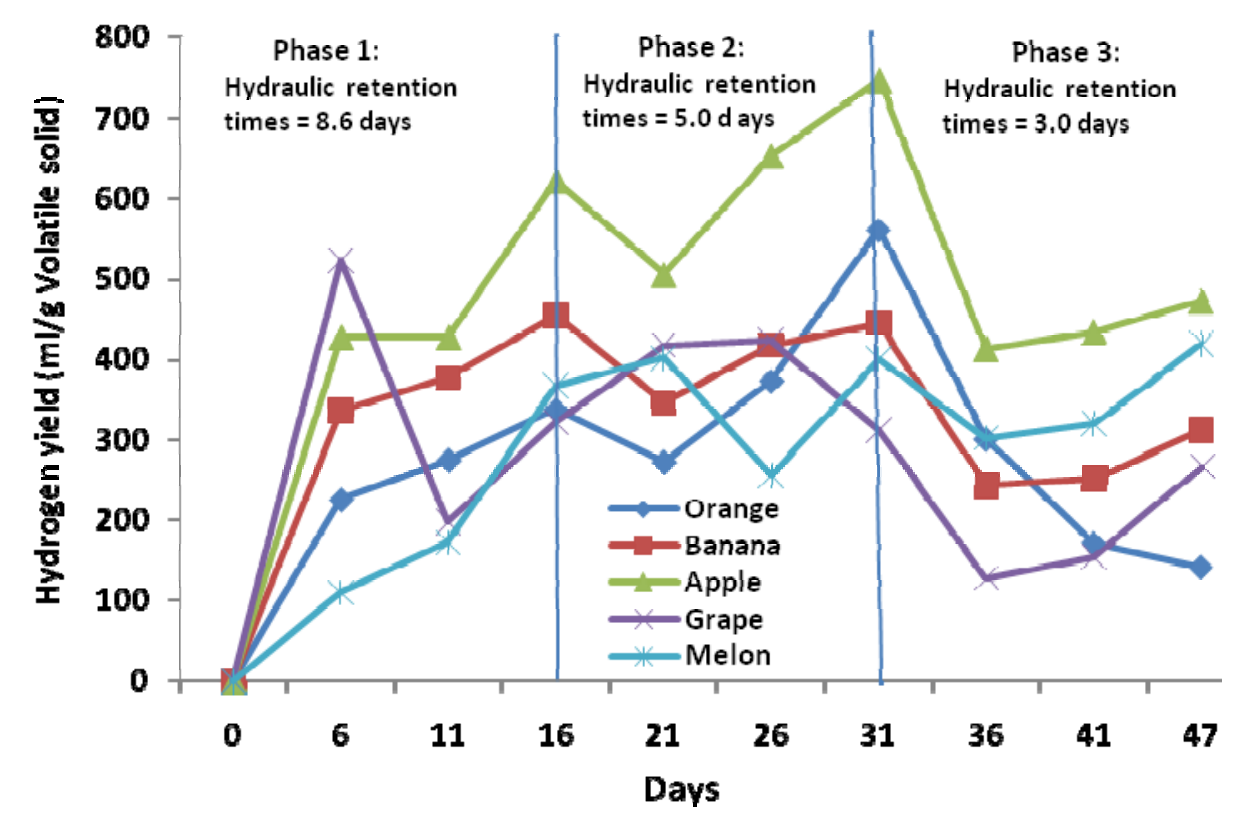

Figure 1. Hydrogen yields from the fermentation of single fruits.

\subsection{Hydrogen Production Yields from Mixed Fruits}

Hydrogen yields from the fermentation of the three fruit mixtures, including 70\% (Mix 1), 50\% (Mix 2) and 20\% (Mix 3) orange share, also followed a similar pattern, but with better performance than the fermentation of individual fruits, except apple (Figure 2). During the first phase, hydrogen yields from Mix 1 and Mix 3 increased, but there was a slight decrease in hydrogen yield from Mix 2. The highest average hydrogen yield of $523 \mathrm{~mL} / \mathrm{gVS}$ obtained during the first phase was from the fermentation of Mix 3. In the second phase, hydrogen yields from Mix 1 and Mix 2 increased, while there was a slight reduction in hydrogen yield from Mix 3. However, Mix 3 produced the highest average hydrogen yield of $553 \mathrm{~mL} / \mathrm{gVS}$ at the end of the second phase. The hydrogen yields from the three fruit mixtures decreased during the last phase, with Mix 3 still producing the highest yield of $491 \mathrm{~mL} / \mathrm{gVS}$. Mix 3 seemed to perform averagely better than other mixed fruits in terms of hydrogen yield. This might be due to the ineffectiveness of the toxicity of the individual inhibitors as a consequent effect of the mutual interaction of the different flavor compounds in the fruit mixture. Besides, since limonene constitutes the major component of citrus essential oils, the reduction of orange percentage in Mix 3 could also impact the reduced antimicrobial effect of limonene in the mixture. Moreover, the use of an appropriate amount of nutrient combination in any mixture of fruit waste is necessary for optimal hydrogen yields from the fermentation process, as excess or insufficient nutrients may affect the stability and gas productivity of the process [34]. The macronutrients ( $\mathrm{Na}, \mathrm{K}, \mathrm{Ca}$ and $\mathrm{Mg}$ ), micronutrients ( $\mathrm{Fe}, \mathrm{Co}, \mathrm{Ni}$ and $\mathrm{Mo}$ ) and some vitamins are necessary for the cell growth and metabolic activities of fermentative microorganism [34-37]. 


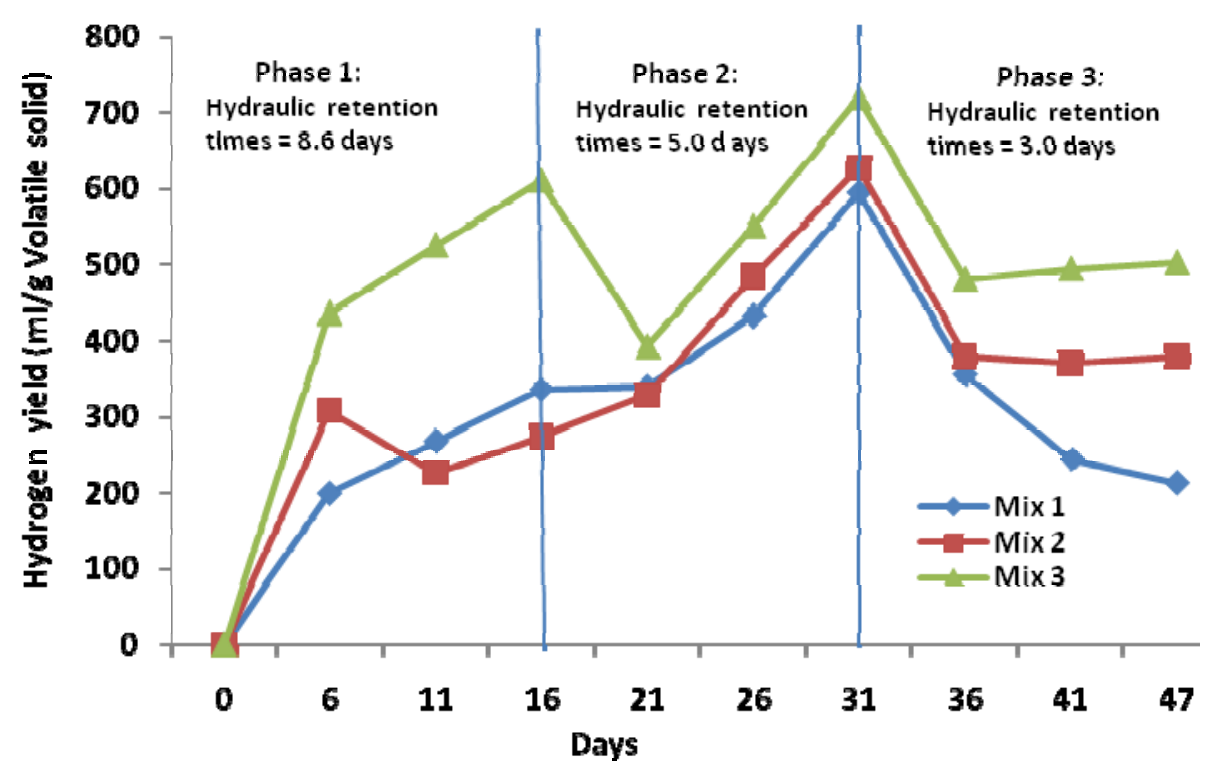

Figure 2. Hydrogen yields from the fermentation of mixed fruits.

\subsection{VFAs Production}

The knowledge of the distribution of VFA compositions formed during the fermentation process is important, as it provides information about the metabolic pathways involved in the process. The distribution of VFA compositions produced during the fermentation of the fruit wastes showed that acetic and butyric acids were the dominant VFAs, while propionic, iso-butyric and iso-valeric were produced in very low amounts (Figure 3). At the end of the first phase of the initial OLR, the acetic acids produced from orange, banana, apple, grape, melon, Mix 1, Mix 2 and Mix 3 were 0.37, 0.62, $0.73,0.75,0.48,0.56,0.74$ and $1.05 \mathrm{~g} / \mathrm{L}$, respectively. As the HRT decreased, the values of the acetic acid increased, except for grape and melon, which decreased during the second phase. At the end of the fermentation process, apple and Mix 3 produced significant amounts of acetic acids, which might be connected to their high cumulative hydrogen yields, as acetic acid production is often associated with hydrogen production [38,39]. 


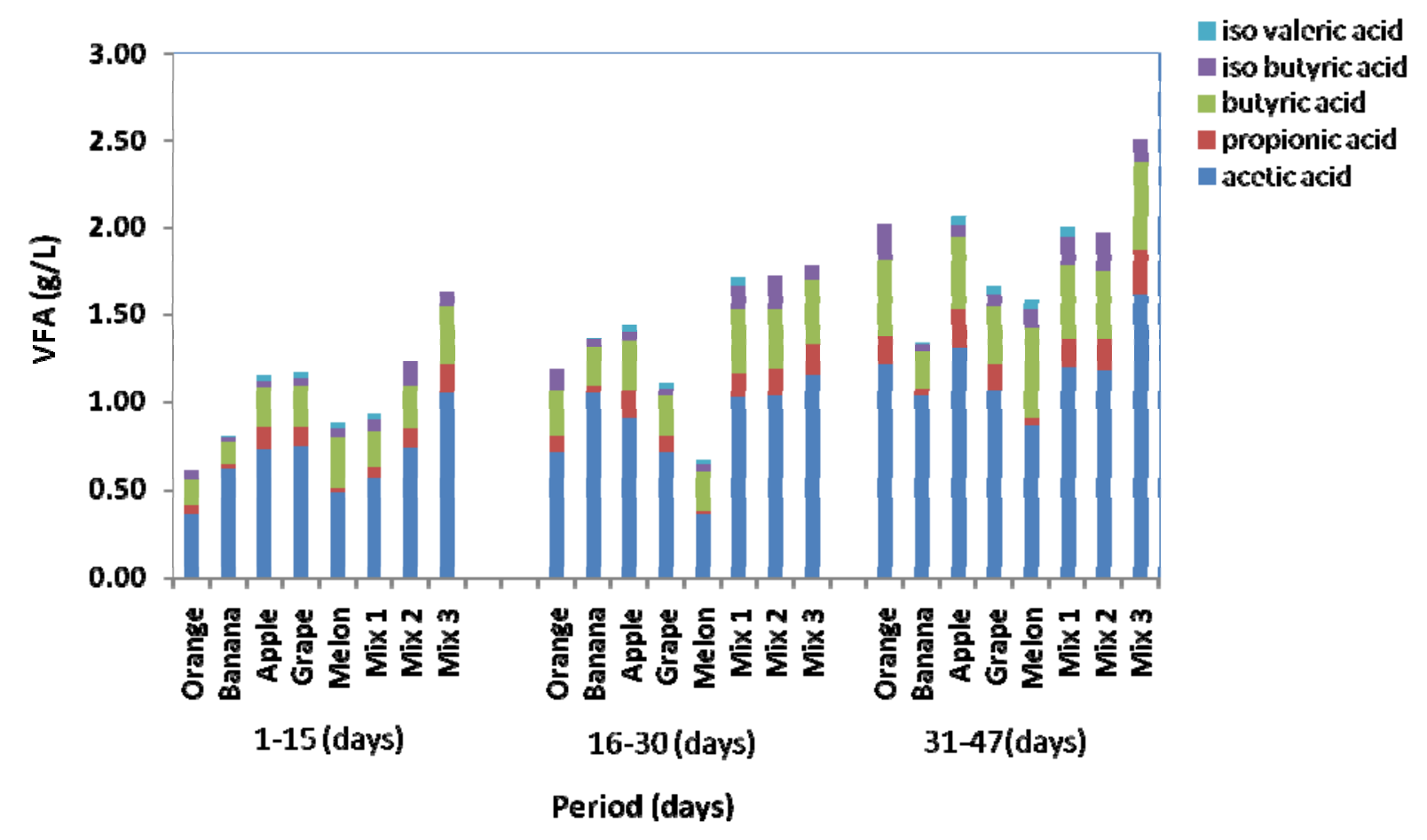

Figure 3. Volatile fatty acid (VFA) composition of the fermentation process.

\subsection{Comparison of Hydrogen Yields and Acetic Acid Productions with Theoretical Values}

In a biological in vivo system, the theoretical maximum hydrogen yield that could be obtained from

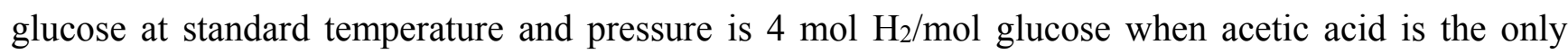
soluble metabolite [40,41]. However, during dark fermentation, hydrogen production is often produced along with reduced metabolites, including alcohols, lactic, propionic and valeric acids, which are involved in the hydrogen consuming pathway, thereby leading to actual hydrogen yields being significantly lower than the theoretical values [42-46]. On the other hand, high hydrogen yields are usually linked with the moderate accumulation of a mixture of acetic and butyric acids though accumulation of butyric acids, and its branched isomer could be an indication of process instability [47]. In the present study, the hydrogen yields from the fermentation of all of the fruit substrates, except grape and melon, increased with the increase in acetic acid production as the HRT decreased from 8.6 down to five days (Table 2). This was expected as the concentration of volatile fatty acids usually increased with the increase in substrate loading, which correlated with the decrease in HRT from 8.6 down to five days [39]. Meanwhile, the hydrogen yields decreased with the increase in acetic acid production, as the HRT was further decreased from five down to three days. In the comparison of actual yields to theoretical yields, the relative yield was calculated as given in Equation (4).

$$
\text { RelativeYield }=\left(\frac{\text { Actual yield }}{\text { Theoretical yield }}\right) \times 100
$$




\subsubsection{Relative Yield of Hydrogen Production}

The theoretical yield of hydrogen was based on Equation (2) with the assumption that at standard temperature and pressure (STP), a maximum of four moles of hydrogen $\left(\mathrm{H}_{2}\right)$ could be produced from one mole of glucose when acetic acid was produced as the only reduced metabolite. The chemical oxygen demand (COD) equivalent of four moles of hydrogen is $1.4 \mathrm{LH}_{2} / \mathrm{g}$ COD of glucose at STP. In other words, $1.4 \mathrm{~L}$ of hydrogen gas could be generated through complete anaerobic degradation of $1 \mathrm{~g}$ COD of glucose at STP. The total COD of the individual fruit waste was calculated, and the equivalent theoretical yield was determined. The theoretical yield estimated and the actual yields obtained experimentally were then used to calculate the relative yield using Equation (4).

Table 2. Comparison of hydrogen yields and acetic acid production with theoretical values.

\begin{tabular}{|c|c|c|c|c|c|c|c|c|c|c|c|c|}
\hline \multirow{4}{*}{$\begin{array}{c}\text { Parameter } \\
\text { Period (d) } \\
\text { HRT (d) } \\
\text { Fruit }\end{array}$} & \multicolumn{6}{|c|}{ Average hydrogen yields } & \multicolumn{6}{|c|}{ Average acetic acid production } \\
\hline & \multicolumn{2}{|l|}{$1-15$} & \multicolumn{2}{|c|}{$16-30$} & \multicolumn{2}{|c|}{$31-47$} & \multicolumn{2}{|c|}{$1-15$} & \multicolumn{2}{|c|}{$16-30$} & \multicolumn{2}{|c|}{$31-47$} \\
\hline & \multicolumn{2}{|l|}{8.6} & \multicolumn{2}{|l|}{5.0} & \multicolumn{2}{|c|}{3.0} & \multicolumn{2}{|c|}{8.6} & \multicolumn{2}{|c|}{5.0} & \multicolumn{2}{|c|}{3.0} \\
\hline & $\begin{array}{c}\mathrm{AY} \\
(\mathrm{mL} / \mathrm{gVS})\end{array}$ & $\begin{array}{l}\text { RY } \\
(\%)\end{array}$ & $\begin{array}{c}\mathrm{AY} \\
(\mathrm{mL} / \mathrm{gVS})\end{array}$ & $\begin{array}{l}\text { RY } \\
(\%)\end{array}$ & $\begin{array}{c}\mathrm{AY} \\
(\mathrm{mL} / \mathrm{gVS})\end{array}$ & $\begin{array}{l}\text { RY } \\
(\%)\end{array}$ & $\begin{array}{c}\mathrm{AY} \\
(\mathrm{g} / \mathrm{L})\end{array}$ & $\begin{array}{l}\text { RY } \\
(\%)\end{array}$ & $\begin{array}{c}\text { AY } \\
(g / L)\end{array}$ & $\begin{array}{l}\text { RY } \\
(\%)\end{array}$ & $\begin{array}{c}\text { AY } \\
(g / L)\end{array}$ & $\begin{array}{l}\text { RY } \\
(\%)\end{array}$ \\
\hline Orange & 279 & 16.1 & 403 & 23.3 & 204 & 11.8 & 0.37 & 55 & 0.71 & 118 & 1.21 & 181 \\
\hline Banana & 389 & 22.7 & 403 & 23.5 & 268 & 15.7 & 0.62 & 93 & 1.05 & 157 & 1.04 & 155 \\
\hline Apple & 493 & 28.9 & 635 & 37.3 & 440 & 25.8 & 0.73 & 109 & 0.91 & 136 & 1.30 & 194 \\
\hline Grape & 347 & 20.5 & 384 & 22.6 & 182 & 10.7 & 0.75 & 112 & 0.71 & 106 & 1.07 & 160 \\
\hline Melon & 216 & 12.6 & 352 & 20.5 & 347 & 20.2 & 0.48 & 72 & 0.37 & 55 & 0.86 & 128 \\
\hline Mix 1 & 268 & 15.5 & 456 & 26.4 & 271 & 15.7 & 0.56 & 84 & 1.03 & 154 & 1.20 & 179 \\
\hline Mix 2 & 270 & 15.7 & 479 & 28.0 & 377 & 22.0 & 0.74 & 110 & 1.03 & 154 & 1.18 & 176 \\
\hline Mix 3 & 523 & 30.5 & 553 & 32.3 & 491 & 28.6 & 1.05 & 157 & 1.15 & 172 & 1.62 & 242 \\
\hline
\end{tabular}

AY, actual yield; RY, relative yield.

Comparing the actual yields to theoretical yields, maximum relative yields of hydrogen production obtained during the three phases were $37.3 \%$ and $32.3 \%$ from apple (single fruit fermentation) and Mix 3 (mixed fruit fermentation), respectively. For the whole fermentation period of 47 days, the maximum relative yields of hydrogen production were $29.5 \%$ and $30.0 \%$ from apple and Mix 3, respectively. On average, this indicates that only $30 \%$ of the chemical oxygen demand in the fruit mixture with Mix 3 could be converted into hydrogen (assuming the fruit wastes could be utilized as glucose). This low value might be due to the effects of the toxicity of the fruit flavors and soluble metabolites.

\subsubsection{Relative Yield of Volatile Fatty Acids}

The theoretical yield of acetic acid production was also based on Equation 2 with the assumption that at standard temperature and pressure (STP), a maximum of two moles of acetic acid $\left(\mathrm{CH}_{3} \mathrm{COOH}\right)$ could be produced from one mole of glucose as the only reduced metabolite. The chemical oxygen demand (COD) equivalent of two moles of acetic acid is $0.666 \mathrm{~g}-\mathrm{O}_{2} / \mathrm{L}$. In the case of acetic acid, the theoretical yield was based on $1 \mathrm{~g}$ COD of the fruit waste. The estimated values of the theoretical acetic acid production and the actual production of acetic acid were then used to calculate the relative yield. 
Throughout the whole fermentation period of 47 days, the maximum acetic acid concentration was $1.62 \mathrm{~g} / \mathrm{L}$ from Mix 3. Although the maximum acetic acid concentration was less than the inhibiting acetic concentration (greater than $2 \mathrm{~g} / \mathrm{L}$ ) [48], the decrease in hydrogen yield during the last fermentation period could have been due to the organic loading exceeding its threshold limit. At a high loading rate, acetic acid might accumulate and permeate the cell membrane of the hydrogen-producing bacteria with subsequent disruption in the activities of the bacteria.

The relative acetic acid yields corresponding to the maximum hydrogen yields were $136 \%$ and $172 \%$ for apple and $20 \%$ orange share, respectively. It appeared that the fermentative bacteria involved in the fermentation of apple and $20 \%$ orange share were able to maintain their cell physiological balance in the presence of extra acetic acids. The reason that some relative yields of acetic acid production were higher than $100 \%$ could be due to the fact that the theoretical yield was based on $1 \mathrm{~g}$ COD of glucose as feedstock, whereas in the real fruit feedstock, the nutrient composition included carbohydrate, protein and lipids that could have been converted into acetic acids.

\subsection{Significant Effects of Varying Hydraulic Retention Times, Fruit Mixing and Their Interaction on Hydrogen Yield and Acetic Acid Production}

The experiment was conducted to investigate the effects of hydraulic retention time (HRT) and fruit mixing, as well as their interactions on hydrogen yield and acetic acid production. The results of the two-way analysis of variance (ANOVA) are summarized in Tables 3 and 4. Based on the results obtained, the hypothesis tests on the effects of hydraulic retention time (HRT) and fruit mixing, as well as their interactions (HRT and fruit mixing interaction) on hydrogen yield indicated that the factors did not have significant effects since their $p$-values, $0.061,0.259$ and 0.763 (Table 3 ) for HRT, fruit mixing and HRT and fruit mixing interaction, respectively, were all greater than the chosen $\alpha$-level (0.05). The results were further corroborated with the Turkey pairwise comparisons for the difference in means (Table 4), which showed that the difference in means of hydrogen yield due to all of the factor levels were not significantly different, since their adjusted $p$-values were all greater than the chosen $\alpha$-level (0.05). Regarding the effects of the factors on acetic acid production, the hypothesis tests (Table 3) showed that HRT and fruit mixing really had significant effects on the production of acetic acids, since their $p$-values of 0.000 and 0.009 for HRT and fruit mixing, respectively, were lower than the chosen $\alpha$-level (0.05). On the contrary, the effect of the interaction of HRT and fruit mixing on acetic acid production was not statistically significant, since its $p$-value $(0.830)$ was greater than the chosen $\alpha$-level (0.05).

The Tukey pairwise comparisons for the difference in means due to HRT (Table 4) showed that the adjusted $p$-values for the differences between the mean for HRT of three days and the means for HRT of five days (0.024) and 8.6 days (0.000) were all lower than the chosen $\alpha$-level (0.05), which indicated that these differences were significant. In the comparison of the difference in means for acetic acid production due to fruit mixing, the adjusted $p$-value (0.009) was lower than the chosen $\alpha$-level (0.05), indicating that the difference was statistically significant.

For the effect of the interaction of HRT and fruit mixing on acetic acid production, the adjusted $p$-values for the difference between the mean for mixed fruit operated at HRT of three days and the means for single fruits operated at HRT of five days (0.010) and 8.6 days $(0.001)$ were lower than the 
chosen $\alpha$-level (0.05). Similarly, the adjusted $p$-values for single fruits (0.010) and mixed fruits (0.037), when operated separately at HRT of three and 8.6 days, were lower than the chosen $\alpha$-level (0.05). Furthermore, the adjusted $p$-value (0.044) for the difference between the mean for mixed fruit operated at HRT of five days and the mean for single fruit operated at HRT of 8.6 days was lower than the chosen $\alpha$-level (0.05), which indicated that the difference was statistically significant.

Meanwhile, as a consequence of the insignificant effect of fruit mixing on hydrogen yield, the fruit feedstock was further considered as individual substrates for analysis of variance (Table 5). Based on the results obtained, the hypothesis tests showed that both HRT and individual substrates had significant effects on hydrogen yields, since their $p$-values (0.001) were lower than the chosen $\alpha$-level (0.05). Similarly, the effects of HRT and individual substrates on acetic acid production were statistically significant, since their $p$-values, 0.000 and 0.001 for HRT and individual substrate, respectively, were lower than the chosen $\alpha$-level (0.05).

Table 3. Summary of two-way analysis of variance (ANOVA) for the effects of hydraulic retention time (HRT) and fruit mixing (Mix) on hydrogen yield and acetic acid production.

\begin{tabular}{|c|c|c|c|c|c|c|c|c|c|}
\hline Response & Factor & Factor Type & Factor Levels & Factor Values & $\mathbf{d F}$ & Adj SS & Adj MS & $F$-Value & $p$-Value \\
\hline \multirow{5}{*}{$\begin{array}{c}\text { Hydrogen } \\
\text { yield }\end{array}$} & HRT & Fixed & 3 & $3.0 ; 5.0 ; 8.6$ & 2 & 3,8951 & 3.28 & 3.28 & 0.061 \\
\hline & Mix & Fixed & 2 & $\mathrm{~N} ; \mathrm{Y}$ & 1 & 16,187 & 1.36 & 1.36 & 0.259 \\
\hline & $\begin{array}{l}\text { HRT and mix } \\
\text { interaction }\end{array}$ & & & & 2 & 3,266 & 0.27 & 0.27 & 0.763 \\
\hline & Error & & & & 18 & 11,890 & & & \\
\hline & Total & & & & 23 & & & & \\
\hline \multirow{5}{*}{$\begin{array}{l}\text { Acetic acid } \\
\text { production }\end{array}$} & HRT & Fixed & 3 & $3.0 ; 5.0: 8.6$ & 2 & 1.05371 & 0.526854 & 12.82 & 0.000 \\
\hline & Mix & Fixed & 2 & $\mathrm{~N}, \mathrm{Y}$ & 1 & 0.35219 & 0.352188 & 8.57 & 0.009 \\
\hline & $\begin{array}{l}\text { HRT and mix } \\
\text { interaction }\end{array}$ & & & & 2 & 0.01551 & 0.007754 & 0.19 & 0.830 \\
\hline & Error & & & & 18 & 0.73985 & 0.041103 & & \\
\hline & Total & & & & 23 & & & & \\
\hline
\end{tabular}

Table 4. Tukey pairwise comparisons: response $=\mathrm{H}_{2}$ yield, acetic acid production; factor $=$ HRT, mix and mix and HRT interaction.

\begin{tabular}{|c|c|c|c|c|c|c|c|}
\hline Response & Factor & $\begin{array}{l}\text { Difference of } \\
\text { factor levels }\end{array}$ & $\begin{array}{c}\text { Difference } \\
\text { of means }\end{array}$ & $\begin{array}{c}\text { SE of } \\
\text { difference }\end{array}$ & $\begin{array}{c}\text { Simultaneous } \\
95 \% \text { CI } \\
\end{array}$ & $t$-value & $\begin{array}{c}\text { Adjusted } \\
p \text {-value }\end{array}$ \\
\hline \multirow{6}{*}{$\mathrm{H}_{2}$ yield } & \multirow{3}{*}{ HRT } & $5.0-3.0$ & 131.8 & 56.3 & $(-12.0 ; 275.5)$ & 2.34 & 0.076 \\
\hline & & $8.6-3.0$ & 15.3 & 56.3 & $(-128.4 ; 159.0)$ & 0.27 & 0.960 \\
\hline & & $8.6-5.0$ & -116.5 & 56.3 & $(-260.2 ; 27.3)$ & -2.07 & 0.125 \\
\hline & \multirow{3}{*}{$\begin{array}{c}\text { Mix } \\
\text { Mix and HRT } \\
\text { interaction }\end{array}$} & YES-NO & 53.6 & 46.0 & $(-42.9 ; 150.2)$ & 1.17 & 0.259 \\
\hline & & $(\mathrm{NO} 5.0)-(\mathrm{NO} 3.0)$ & 147.2 & 69.0 & $(-71.8 ; 366.2)$ & 2.13 & 0.314 \\
\hline & & $(\mathrm{NO} 8.6)-(\mathrm{NO} 3.0)$ & 56.6 & 69.0 & $(-162.4 ; 275.6)$ & 0.82 & 0.960 \\
\hline
\end{tabular}


Table 4. Cont.

\begin{tabular}{|c|c|c|c|c|c|c|c|}
\hline Response & Factor & $\begin{array}{l}\text { Difference of } \\
\text { factor levels }\end{array}$ & $\begin{array}{c}\text { Difference } \\
\text { of means }\end{array}$ & $\begin{array}{c}\text { SE of } \\
\text { difference }\end{array}$ & $\begin{array}{c}\text { Simultaneous } \\
95 \% \text { CI } \\
\end{array}$ & $t$-value & $\begin{array}{c}\text { Adjusted } \\
p \text {-value }\end{array}$ \\
\hline & & (YES 3.0)-(NO 3.0) & 91.5 & 79.6 & $(-161.4 ; 344.3)$ & 1.15 & 0.855 \\
\hline & & (YES 5.0)-(NO 3.0) & 207.8 & 79.6 & $(-45.0 ; 460.6)$ & 2.61 & 0.145 \\
\hline & & (YES 8.6)-(NO 3.0) & 65.5 & 79.6 & $(-187.4 ; 318.3)$ & 0.82 & 0.960 \\
\hline & & $(\mathrm{NO} 8.6)-(\mathrm{NO} 5.0)$ & -90.6 & 69.0 & $(-309.6 ; 128.4)$ & -1.31 & 0.774 \\
\hline & & (YES 3.0)-(NO 5.0) & -55.7 & 79.6 & $(-308.6 ; 197.1)$ & -0.70 & 0.980 \\
\hline & & (YES 5.0)-(NO 5.0) & 60.6 & 79.6 & $(-192.2 ; 313.4)$ & 0.76 & 0.971 \\
\hline & & (YES 8.6)-(NO 5.0) & -81.7 & 79.6 & $(-334.6 ; 171.1)$ & -1.03 & 0.903 \\
\hline & & (YES 3.0)-(NO 8.6) & 34.9 & 79.6 & $(-218.0 ; 287.7)$ & 0.44 & 0.998 \\
\hline & & (YES 5.0)-(NO 8.6) & 151.2 & 79.6 & $(-101.6 ; 404.0)$ & 1.90 & 0.434 \\
\hline & & (YES 8.6)-(NO 8.6) & 8.9 & 79.6 & $(-244.0 ; 261.7)$ & 0.11 & 1.000 \\
\hline & & (YES 5.0)-(YES 3.0) & 116.3 & 89.0 & $(-166.3 ; 399.0)$ & 1.31 & 0.778 \\
\hline & & (YES 8.6)-(YES 3.0) & -26.0 & 89.0 & $(-308.7 ; 256.7)$ & -0.29 & 1.000 \\
\hline & & (YES 8.6)-(YES 5.0) & -142.3 & 89.0 & $(-425.0 ; 140.3)$ & -1.60 & 0.610 \\
\hline \multirow{19}{*}{ Acetic acid } & HRT & $5.0-3.0$ & -0.305 & 0.105 & $(-0.572 ;-0.037)$ & -2.91 & 0.024 \\
\hline & & $8.6-3.0$ & -0.528 & 0.105 & $(-0.795 ;-0.261)$ & -5.04 & 0.000 \\
\hline & & $8.6-5.0$ & -0.223 & 0.105 & $(-0.491 ; 0.044)$ & -2.13 & 0.111 \\
\hline & Mix & YES-NO & 0.2502 & 0.0855 & $(0.0706 ; 0.4298)$ & 2.93 & 0.124 \\
\hline & $\begin{array}{l}\text { Mix and HRT } \\
\text { interaction }\end{array}$ & $(\mathrm{NO} 5.0)-(\mathrm{NO} 3.0)$ & -0.346 & 0.128 & $(-0.753 ; 0.061)$ & -2.70 & 0.124 \\
\hline & & $(\mathrm{NO} 8.6)-(\mathrm{NO} 3.0)$ & -0.506 & 0.128 & $(-0.913 ;-0.099)$ & -3.95 & 0.010 \\
\hline & & (YES 3.0)-(NO 3.0) & 0.237 & 0.148 & $(-0.233 ; 0.707)$ & 1.60 & 0.607 \\
\hline & & (YES 5.0)-(NO 3.0) & -0.026 & 0.148 & $(-0.496 ; 0.444)$ & -0.18 & 1.000 \\
\hline & & (YES 8.6)-(NO 3.0) & -0.313 & 0.148 & $(-0.783 ; 0.157)$ & -2.11 & 0.325 \\
\hline & & $(\mathrm{NO} 8.6)-(\mathrm{NO} 5.0)$ & -0.160 & 0.128 & $(-0.567 ; 0.247)$ & -1.25 & 0.808 \\
\hline & & (YES 3.0)-(NO 5.0) & 0.583 & 0.148 & $(0.113 ; 1.053)$ & 3.94 & 0.010 \\
\hline & & (YES 5.0)-(NO 5.0) & 0.320 & 0.148 & $(-0.150 ; 0.790)$ & 2.16 & 0.302 \\
\hline & & (YES 8.6)-(NO 5.0) & 0.033 & 0.148 & $(-0.437 ; 0.503)$ & 0.23 & 1.000 \\
\hline & & (YES 3.0)-(NO 8.6) & 0.743 & 0.148 & $(0.273 ; 1.213)$ & 5.02 & 0.001 \\
\hline & & (YES 5.0)-(NO 8.6) & 0.480 & 0.148 & $(0.010 ; 0.950)$ & 3.24 & 0.044 \\
\hline & & (YES 8.6)-(NO 8.6) & 0.193 & 0.148 & $(-0.227 ; 0.663)$ & 1.31 & 0.778 \\
\hline & & (YES 5.0)-(YES 3.0) & -0.263 & 0.166 & $(-0.789 ; 0.262)$ & -1.59 & 0.614 \\
\hline & & (YES 8.6)-(YES 3.0) & -0.550 & 0.166 & $(-1.076 ;-0.024)$ & -3.32 & 0.037 \\
\hline & & (YES 8.6)-(YES 5.0) & -0.287 & 0.166 & $(-0.812 ; 0.239)$ & -1.73 & 0.530 \\
\hline
\end{tabular}


Table 5. Summary of two-way analysis of variance (ANOVA) for the effects of hydraulic retention time (HRT) and substrate.

\begin{tabular}{|c|c|c|c|c|c|c|c|c|c|}
\hline Response & Factor & Factor Type & Factor Levels & Factor Values & dF & Adj SS & Adj MS & F-Value & $p$-Value \\
\hline \multirow{4}{*}{$\begin{array}{l}\text { Hydrogen } \\
\text { yield }\end{array}$} & HRT & Fixed & 3 & \multirow{4}{*}{$\begin{array}{l}\text { 3.0; 5.0; } 8.6 \\
\text { Apple; Banana; Grape; Melon; } \\
\text { Mix1; Mix 2; Mix 3; Orange }\end{array}$} & 2 & 83,069 & 41,534 & 11.52 & 0.001 \\
\hline & Substrate & Fixed & 8 & & 7 & 186,264 & 26,609 & \multirow[t]{3}{*}{7.38} & \multirow[t]{3}{*}{0.001} \\
\hline & Error & & & & 14 & 50,472 & \multirow[t]{2}{*}{3,605} & & \\
\hline & Total & & & & 23 & 319,805 & & & \\
\hline & HRT & Fixed & 3 & $3.0 ; 5.0 ; 8.6$ & 2 & 1.1074 & 0.55372 & 30.39 & 0.000 \\
\hline $\begin{array}{l}\text { Acetic } \\
\text { acid }\end{array}$ & Mix & Fixed & 8 & $\begin{array}{l}\text { Apple; Banana; Grape; Melon; } \\
\text { Mix1; Mix 2; Mix 3; Orange }\end{array}$ & 7 & 0.8524 & 0.12178 & 6.68 & 0.001 \\
\hline \multirow[t]{2}{*}{ production } & Error & & & & 14 & 0.2551 & 0.01822 & & \\
\hline & Total & & & & 23 & & & & \\
\hline
\end{tabular}

The Tukey pairwise comparisons for the difference in means of hydrogen yield due to HRT (Table 6) showed that the adjusted $p$-values for the differences between the mean for HRT of five days and the means for HRT of three days (0.001) and 8.6 days (0.007) were lower than the chosen $\alpha$-level (0.05), which indicated that these differences were significant. For the effects of individual substrates on hydrogen yield, the Turkey pairwise comparisons showed that the adjusted $p$-values for the differences between the mean for apple and the means for grape (0.010), melon (0.010), Mix 1 (0.026) and orange (0.007) were all lower than the chosen $\alpha$-level (0.05). In the same vein, the adjusted $p$-values for the difference between the mean for Mix 3 and the means for grape (0.010), melon (0.010), Mix $1(0.026)$ and orange (0.007) were lower than the chosen $\alpha$-level (0.05), which indicated that the mean differences were significant. Meanwhile, the Tukey comparison for the difference in means of acetic acid production due to HRT showed that the adjusted $p$-values for the differences between the mean for HRT of three days and the means for HRT of five days (0.001) and 8.6 days (0.0022) were lower than the chosen $\alpha$-level (0.05). Furthermore, the adjusted $p$-value (0.021) for the difference between the mean for HRT of five days and 8.6 days was lower than the chosen $\alpha$-level $(0.05)$, which indicated that the difference was significant. In the case of the effects of individual substrates on acetic acid production, the adjusted $p$-values for the differences between the mean for Mix 3 and the means for grape (0.026), melon (0.000) and orange (0.007) were below the chosen $\alpha$-level (0.05). Similarly, the adjusted $p$-values for the difference between the mean for melon and the means for apple (0.036) and Mix 2 (0.034) were below the chosen $\alpha$-level (0.05), which showed that the mean differences were significant. 
Table 6. Tukey pairwise comparisons: Response $=\mathrm{H}_{2}$ yield, acetic acid production; factor $=$ HRT, substrate.

\begin{tabular}{|c|c|c|c|c|c|c|c|}
\hline Response & Factor & $\begin{array}{c}\text { Difference of } \\
\text { Factor Levels }\end{array}$ & $\begin{array}{c}\text { Difference } \\
\text { of Means }\end{array}$ & $\begin{array}{c}\text { SE of } \\
\text { Difference }\end{array}$ & $\begin{array}{c}\text { Simultaneous } \\
95 \% \text { CI }\end{array}$ & t-Value & $\begin{array}{c}\text { Adjusted } \\
p \text {-Value }\end{array}$ \\
\hline & & $5.0-3.0$ & 135.6 & 30.0 & $(57.1 ; 214.2)$ & 4.52 & 0.001 \\
\hline \multirow[t]{31}{*}{$\mathrm{H}_{2}$ yield } & HRT & $8.6-3.0$ & 25.6 & 30.0 & $(-52.9 ; 104.2)$ & 0.85 & 0.677 \\
\hline & & $8.6-5.0$ & -110.0 & 30.0 & $(-188.5 ;-31.5)$ & -3.66 & 0.007 \\
\hline & Substrate & Banana-Apple & -169.3 & 49.0 & $(-342.3 ; 3.6)$ & -3.45 & 0.057 \\
\hline & & Grape-apple & -218.3 & 49.0 & $(-391.3 ;-45.4)$ & -4.45 & 0.010 \\
\hline & & Melon-Apple & -217.7 & 49.0 & $(-390.6 ;-44.7)$ & -4.44 & 0.010 \\
\hline & & Mix 1-Apple & -191.0 & 49.0 & $(-364.0 ;-18.0)$ & -3.90 & 0.026 \\
\hline & & Mix 2-Apple & -147.3 & 49.0 & $(-320.3 ; 25.6)$ & -3.01 & 0.123 \\
\hline & & Mix 3-Apple & -0.3 & 49.0 & $(-173.3 ; 172.6)$ & -0.01 & 1.000 \\
\hline & & Orange-Apple & -227.3 & 49.0 & $(-400.3 ;-54.4)$ & -4.64 & 0.007 \\
\hline & & Grape-Banana & -49.0 & 49.0 & $(-222.0 ; 124.6)$ & -1.00 & 0.967 \\
\hline & & Melon-Banana & -48.3 & 49.0 & $(-221.3 ; 124.6)$ & -0.99 & 0.969 \\
\hline & & Mix 1-Banana & -21.7 & 49.0 & $(-194.6 ; 151.3)$ & -0.44 & 1.000 \\
\hline & & Mix 2-Banana & 22.0 & 49.0 & $(-151.0 ; 195.0)$ & 0.45 & 1.000 \\
\hline & & Mix 3-Banana & 169.0 & 49.0 & $(-4.0 ; 342.0)$ & 3.45 & 0.058 \\
\hline & & Orange-Banana & -58.0 & 49.0 & $(-231.0 ; 115.0)$ & -1.18 & 0.924 \\
\hline & & Melon-Grape & 0.7 & 49.0 & $(-172.3 ; 173.6)$ & 0.01 & 1.000 \\
\hline & & Mix 1-Grape & 27.3 & 49.0 & $(-145.6 ; 200.3)$ & 0.56 & 0.999 \\
\hline & & Mix 2-Grape & 71.0 & 49.0 & $(-102.0 ; 244.0)$ & 1.45 & 0.821 \\
\hline & & Mix 3-Grape & 218.0 & 49.0 & $(45.0 ; 391.0)$ & 4.45 & 0.010 \\
\hline & & Orange- Grape & -9.0 & 49.0 & $(-182.0 ; 164.0)$ & -0.18 & 1.000 \\
\hline & & Mix 1-Melon & 26.7 & 49.0 & $(-146.3 ; 199.6)$ & 0.54 & 0.999 \\
\hline & & Mix 2-Melon & 70.3 & 49.0 & $(-102.6 ; 243.3)$ & 1.43 & 0.827 \\
\hline & & Mix 3-Melon & 217.3 & 49.0 & $(44.4 ; 390.3)$ & 4.43 & 0.010 \\
\hline & & Orange-Melon & -9.7 & 49.0 & $(-182.6 ; 163.3)$ & -0.20 & 1.000 \\
\hline & & Mix 2-Mix 1 & 43.7 & 49.0 & $(-129.3 ; 216.6)$ & 0.89 & 0.982 \\
\hline & & Mix 3-Mix 1 & 190.7 & 49.0 & $(17.7 ; 363.6)$ & 3.89 & 0.026 \\
\hline & & Orange-Mix 1 & -36.3 & 49.0 & $(-209.3 ; 136.6)$ & -0.74 & 0.994 \\
\hline & & Mix 3-Mix 2 & 147.0 & 49.0 & $(-26.0 ; 320.0)$ & 3.00 & 0.124 \\
\hline & & Orange-Mix 2 & -80.0 & 49.0 & $(-253.0 ; 93.0)$ & -1.63 & 0.726 \\
\hline & & Orange-Mix 3 & -227.0 & 49.0 & $(-400.0 ;-54.0)$ & -4.63 & 0.007 \\
\hline & & $5.0-3.0$ & -0.3150 & 0.0675 & $(-0.4916 ;-0.1384)$ & -4.67 & 0.001 \\
\hline \multirow[t]{10}{*}{ Acetic acid } & HRT & $8.6-3.0$ & -0.5225 & 0.0675 & $(-0.6991 ;-0.3459)$ & -7.74 & 0.002 \\
\hline & & $8.6-5.0$ & -0.2075 & 0.0675 & $(-0.3841 ;-0.0309)$ & -3.07 & 0.021 \\
\hline & Substrate & Banana-Apple & -0.077 & 0.110 & $(-0.466 ; 0.312)$ & -0.70 & 0.996 \\
\hline & & Grape-apple & -0.137 & 0.110 & $(-0.526 ; 0.252)$ & -1.24 & 0.906 \\
\hline & & Melon-Apple & -0.410 & 0.110 & $(-0.799 ;-0.021)$ & -3.72 & 0.036 \\
\hline & & Mix 1-Apple & -0.050 & 0.110 & $(-0.439 ; 0.339)$ & -0.45 & 1.000 \\
\hline & & Mix 2-Apple & 0.003 & 0.110 & $(-0.386 ; 0.392)$ & 0.03 & 1.000 \\
\hline & & Mix 3-Apple & 0.293 & 0.110 & $(-0.096 ; 0.682)$ & 2.66 & 0.213 \\
\hline & & Orange-Apple & -0.217 & 0.110 & $(-0.606 ; 0.172)$ & -1.97 & 0.534 \\
\hline & & Grape-Banana & -0.060 & 0.110 & $(-0.449 ; 0.329)$ & -0.54 & 0.999 \\
\hline
\end{tabular}


Table 6. Cont.

\begin{tabular}{|c|c|c|c|c|c|c|c|}
\hline Response & Factor & $\begin{array}{l}\text { Difference of } \\
\text { Factor Levels }\end{array}$ & $\begin{array}{l}\text { Difference } \\
\text { of Means }\end{array}$ & $\begin{array}{c}\text { SE of } \\
\text { Difference }\end{array}$ & $\begin{array}{c}\text { Simultaneous } \\
95 \% \text { CI }\end{array}$ & t-Value & $\begin{array}{c}\text { Adjusted } \\
p \text {-Value }\end{array}$ \\
\hline & & Melon-Banana & -0.333 & 0.110 & $(-0.722 ; 0.056)$ & -3.02 & 0.119 \\
\hline & & Mix 1-Banana & 0.027 & 0.110 & $(-0.362 ; 0.416)$ & 0.24 & 1.000 \\
\hline & & Mix 2-Banana & 0.080 & 0.110 & $(-0.309 ; 0.469)$ & 0.73 & 0.995 \\
\hline & & Mix 3-Banana & 0.370 & 0.110 & $(-0.019 ; 0.759)$ & 3.36 & 0.068 \\
\hline & & Orange-Banana & -0.140 & 0.110 & $(-0.529 ; 0.249)$ & -1.27 & 0.896 \\
\hline & & Melon-Grape & -0.273 & 0.110 & $(-0.662 ; 0.116)$ & -2.48 & 0.278 \\
\hline & & Mix 1-Grape & 0.087 & 0.110 & $(-0.302 ; 0.476)$ & 0.79 & 0.991 \\
\hline & & Mix 2-Grape & 0.140 & 0.110 & $(-0.249 ; 0.529)$ & 1.27 & 0.896 \\
\hline & & Mix 3-Grape & 0.430 & 0.110 & $(0.041 ; 0.819)$ & 3.90 & 0.026 \\
\hline & & Orange- Grape & -0.080 & 0.110 & $(-0.469 ; 0.309)$ & -0.73 & 0.995 \\
\hline & & Mix 1-Melon & 0.360 & 0.110 & $(-0.029 ; 0.749)$ & 3.27 & 0.079 \\
\hline & & Mix 2-Melon & 0.413 & 0.110 & $(0.024 ; 0.802)$ & 3.75 & 0.034 \\
\hline & & Mix 3-Melon & 0.703 & 0.110 & $(0.314 ; 1.092)$ & 6.38 & 0.000 \\
\hline & & Orange-Melon & 0.193 & 0.110 & $(-0.196 ; 0.582)$ & 1.75 & 0.657 \\
\hline & & Mix 2-Mix 1 & 0.053 & 0.110 & $(-0.336 ; 0.422)$ & 0.48 & 1.000 \\
\hline & & Mix 3-Mix 1 & 0.343 & 0.110 & $(-0.046 ; 0.732)$ & 3.12 & 0.102 \\
\hline & & Orange-Mix 1 & -0.167 & 0.110 & $(-0.556 ; 0.222)$ & -1.51 & 0.790 \\
\hline & & Mix 3-Mix 2 & 0.290 & 0.110 & $(-0.099 ; 0.679)$ & 2.63 & 0.223 \\
\hline & & Orange-Mix 2 & -0.220 & 0.110 & $(-0.609 ; 0.169)$ & -2.00 & 0.516 \\
\hline & & Orange-Mix 3 & -0.510 & 0.110 & $(-0.899 ;-0.121)$ & -4.63 & 0.007 \\
\hline
\end{tabular}

\section{Experimental Section}

\subsection{Experimental Materials (Feedstock, Seed Sludge and Nutrient)}

Whole fruit wastes, including apple (Malus sp.), banana (Musa sp.), grape (Vitis sp.), melon (Cucumis sp.) and orange (Citrus sp.), obtained from a local shop (Borås, Sweden), were used as feedstock for the anaerobic digestion process. The fruits as a whole (rind and inner part of the fruits) were ground separately in a kitchen blender (Waring Commercial, Torrington, CT, USA) before they were stored in a cold room $\left(5{ }^{\circ} \mathrm{C}\right)$ to reduce their deterioration prior to the fermentation process. The hydrogen-producing microorganism (HPM) was prepared from sludge obtained from a thermophilic $\left(55^{\circ} \mathrm{C}\right)$ biogas plant (Borås Energi \& Miljö $\mathrm{AB}$, Borås, Sweden) that utilized the organic fraction of municipal solid waste as feedstock for biogas production. The HPM was enriched by adjusting the $\mathrm{pH}$ to $5.0 \pm 0.1$ coupled with heat treatment at $105{ }^{\circ} \mathrm{C}$ for $1 \mathrm{~h}$. The nutrients used for the growth of HPM were a mixture of macro- and micronutrients, including (g/L): $\mathrm{FeCl}_{2} .4 \mathrm{H}_{2} \mathrm{O}, 11.401$; $\mathrm{KH}_{2} \mathrm{PO}_{4}, 4.681 ; \mathrm{NH}_{4} \mathrm{Cl}, 0.814 ; \mathrm{NaHCO} 3,3.000 ; \mathrm{MgSO}_{4} .7 \mathrm{H}_{2} \mathrm{O}, 0.320 ; \mathrm{NiSO}_{4} .6 \mathrm{H}_{2} \mathrm{O}, 0.032 ; \mathrm{CaCl}_{2}$, 0.050; $\left.\mathrm{Na}_{2} \mathrm{~B}_{4} \mathrm{O}_{7} .10 \mathrm{H}_{2} \mathrm{O}, 0.007 ; \quad \mathrm{NH}_{4}\right)_{6} \mathrm{Mo}_{7} \mathrm{O}_{24 .} 4 \mathrm{H}_{2} \mathrm{O}, 0.014: \mathrm{ZnCl}_{2}, 0.023 ; \mathrm{CoCl}_{6} . \mathrm{H}_{2} \mathrm{O}, 0.021$; $\mathrm{CuCl}_{2} .2 \mathrm{H}_{2} \mathrm{O}, 0.010$. 


\subsection{Experimental Setup and Procedures}

The fermentative production of hydrogen was carried out using eight continuous stirred tank bioreactors (CSTR) in order to evaluate the performance, in terms of hydrogen yields and VFA production, of the fermentative hydrogen production process from the whole fruit wastes. Each CSTR reactor (active volume of $3 \mathrm{~L}$ and headspace of $1 \mathrm{~L}$ ) contained fermentation medium at $55{ }^{\circ} \mathrm{C}$ and a pH of 5.0 (Figure 4). Eight different fruit substrates were used, including single fruits (banana, apple, grape, melon, orange) and mixed fruits, which differed in the amount of orange in the mixtures. The weight distribution of the first, second and third fruit mixtures were $70 \%, 50 \%$ and $20 \%$ orange share, respectively, while the residual weight was shared equally by banana, apple, grape, melon and orange. A thermostatic water bath (GD 100, Grant instruments Ltd., Cambridgeshire, UK) was employed to provide the heating energy needed to maintain the required temperatures in the CSTRs. Prior to the start of the fermentation process, the fruit slurries were left to attain room temperature $\left(22{ }^{\circ} \mathrm{C}\right)$ before they were fed into the bioreactors. A mixture of HPM, feedstock, distilled water, macro- and micro-nutrients in solution at a volumetric ratio of $8: 2: 6: 4: 1$, respectively, was added to the CSTRs and left for three days without any daily feedstock feeding in order to adapt or acclimatize the inoculum to the fermentation environment. The fermentation process was started, after the third day, with the feeding of the fruit feedstock mixed with distilled water, buffer solution (1 $\mathrm{M} \mathrm{NaHCO}$ ), macro- and micro-nutrients at a ratio of 10:60:3:20:7, respectively, into the CSTR. The whole experiment was run for 47 days with an increase in the organic loading rate (OLR).

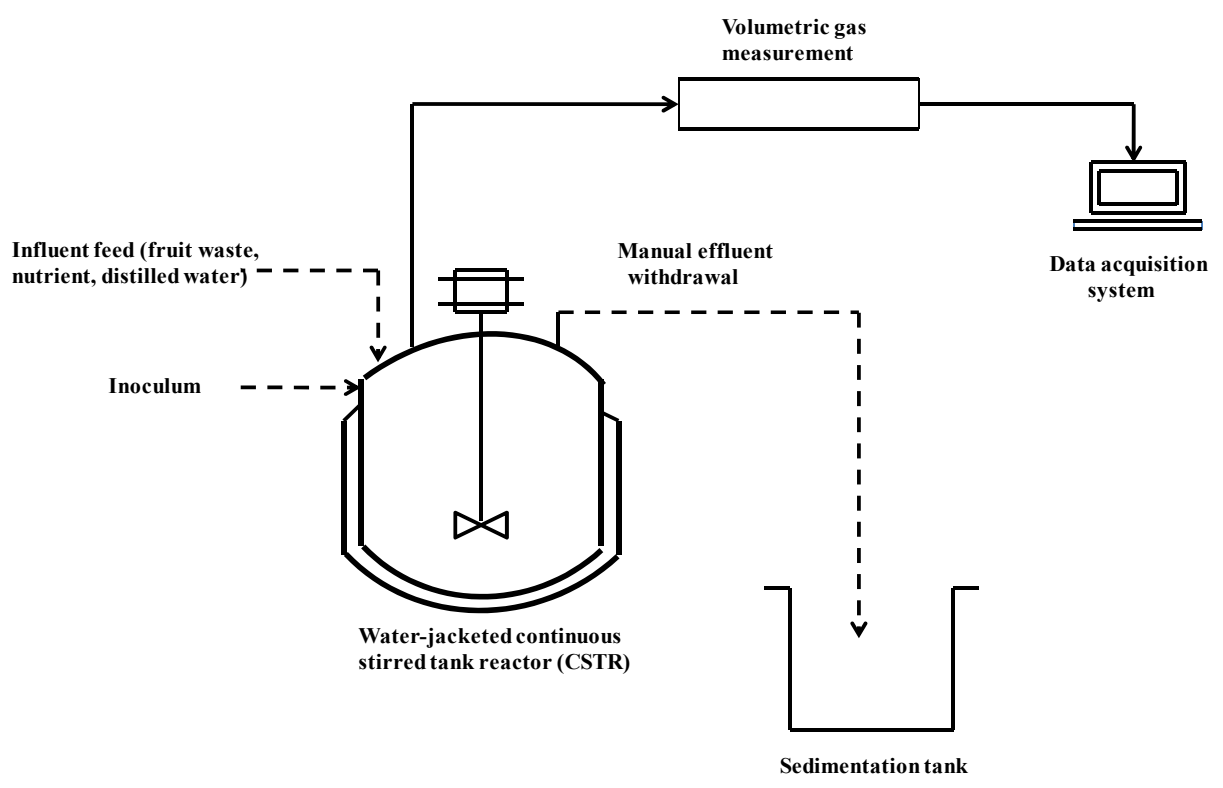

Figure 4. Schematic diagram of the fermentative hydrogen production from single and mixed fruits.

\subsection{Analytical Procedures}

The characteristics of the feedstock for the two-stage fermentation process, including total solid (TS), volatile solid (VS) and $\mathrm{pH}$ (Table 7), were determined according to standard methods [49]. The main nutrient compositions of the fruit wastes and their mixtures are presented in Table 8 according to the nutrient database of the U.S. Department of Agriculture [50]. The gas produced was measured 
using the Automatic Methane Potential Testing System (AMPTS, Bioprocess Control AB, Lund, Sweden), which is based on the principle of water displacement and buoyancy, while the hydrogen composition of the gas produced was sampled with the aid of a $0.25-\mu \mathrm{L}$ pressure-tight gas syringe (VICI, Baton Rouge, LA, USA) and analyzed using a gas chromatograph (GC, Perkin-Elmer, 710 Bridgeport Avenue, Shelton, CT, USA) equipped with a packed column (Perkin-Elmer, 6' × 1.8" OD, 80/100, Mesh, 710 Bridgeport Avenue, Shelton, CT, USA) and a thermal conductivity detector (TCD, PerkinElmer, 710 Bridgeport Avenue, Shelton, CT, USA) set at $200{ }^{\circ} \mathrm{C}$. The temperatures of the oven and injector were set at $75{ }^{\circ} \mathrm{C}$ and $150{ }^{\circ} \mathrm{C}$, respectively, while nitrogen gas at a flow rate, temperature and pressure of $20 \mathrm{~mL} / \mathrm{min}, 60^{\circ} \mathrm{C}$ and $1 \mathrm{bar}$, respectively, was used as the carrier gas. The volatile fatty acids (VFA) in the effluent samples were measured using a high-performance liquid chromatograph (HPLC, Waters 2695, Waters Corporation, Milford, MA, USA) equipped with an RI detector (Waters 2414, Waters Corporation, Milford, MA, USA) and a biohydrogen-ion exchange column (Aminex HPX-87H, Bio-Rad, Hercules, CA, USA) operating at $60{ }^{\circ} \mathrm{C}$ and $0.6 \mathrm{~mL} / \mathrm{min}$ and with $5 \mathrm{mM}$ sulfuric acid as the effluent.

Table 7. Measured characteristics of fruit wastes. TS, total solid.

\begin{tabular}{cccccc}
\hline Parameters & Apple & Banana & Grape & Melon & Orange \\
\hline TS (\%) & $11.72 \pm 0.02$ & $16.36 \pm 0.24$ & $19.32 \pm 0.24$ & $8.93 \pm 0.26$ & $16.85 \pm 0.30$ \\
VS (\%) & $11.53 \pm 0.35$ & $15.5 \pm 0.05$ & $18.68 \pm 0.06$ & $8.39 \pm 0.16$ & $16.26 \pm 0.20$ \\
pH & $3.90 \pm 0.01$ & $5.06 \pm 0.02$ & $3.67 \pm 0.02$ & $4.88 \pm 0.01$ & $4.04 \pm 0.02$ \\
\hline
\end{tabular}

Table 8. Nutrient composition in $100 \mathrm{~g}$ of fruit.

\begin{tabular}{|c|c|c|c|c|c|c|c|}
\hline \multirow{2}{*}{ Fruit } & \multicolumn{2}{|c|}{ Carbohydrate } & \multicolumn{2}{|c|}{ Protein } & \multicolumn{2}{|c|}{ Lipid } & \multirow{2}{*}{ C:N Ratio * } \\
\hline & g & $\%$ & g & $\%$ & $\mathbf{g}$ & $\%$ & \\
\hline Apple & 14.06 & 97 & 0.27 & 2 & 0.20 & 1 & $52: 1$ \\
\hline Melon & 9.09 & 93 & 0.54 & 6 & 0.14 & 1 & $17: 1$ \\
\hline Banana & 22.84 & 94 & 1.09 & 5 & 0.33 & 1 & $21: 1$ \\
\hline Orange & 15.50 & 90 & 1.30 & 8 & 0.30 & 2 & $12: 1$ \\
\hline Grape & 18.10 & 95 & 0.72 & 4 & 0.16 & 1 & $25: 1$ \\
\hline Mix $1 *$ & 15.71 & 92 & 1.10 & 6 & 0.28 & 2 & $14: 1$ \\
\hline $\operatorname{Mix} 2 *$ & 15.77 & 95 & 0.59 & 3 & 0.26 & 2 & $27: 1$ \\
\hline Mix $3 *$ & 15.92 & 94 & 0.78 & 5 & 0.23 & 1 & $20: 1$ \\
\hline
\end{tabular}

\section{Conclusions}

The present study assessed the effect of hydraulic retention times and fruit mixing on biohydrogen production from fruit wastes in continuous stirred tank bioreactors. The results of the two-way analysis of variance indicated that there was no statistically-significant effect of the interaction of hydraulic retention time and fruit mixing on hydrogen yields and acetic acid production. However, the results established that significant improvement in hydrogen yields could be obtained when apple and Mix 3 were used as individual substrates. The results also indicated that operating the fermentative hydrogen production at a hydraulic retention time of 5 days could greatly increase hydrogen yield, as it reduced 
the amount of acetic acid accumulated during the fermentation process. It could therefore be inferred that fermentation of apple or Mix 3 at hydraulic retention time of 5 days could be used to reduce the effect of bacterial inhibition due to flavor compounds in the fruits and thereby enhance hydrogen production from the fruit wastes.

\section{Acknowledgments}

The authors wish to express their gratitude to the Swedish Research Council (Sweden) and Lagos State University (Nigeria) for providing financial support during the research work. We are also grateful for the assistance given by Magnus Lundin on statistical analysis of the data and to Khamdan Cahyari for his support during the study.

\section{Acronyms}

$\begin{array}{llll}\text { AY } & \text { Actual yield } & \text { CIs } & \text { Confidence intervals } \\ \text { COD } & \text { Chemical oxygen demand } & \text { dF } & \text { degree of freedom } \\ \text { HPM } & \text { Hydrogen producing microorganism } & \text { HRT } & \text { Hydraulic retention time } \\ \text { MS } & \text { Mean square } & \text { Mix } & \text { Mixing } \\ \text { Mix 1 } & 70 \% \text { orange mixed fruit } & \text { Mix } 2 & 50 \% \text { orange mixed fruit } \\ \text { Mix 3 } & \text { 20\% orange mixed fruit } & \text { OLR } & \text { Organic loading rate } \\ \text { PY } & \text { Percent yield } & \text { SS } & \text { Sum of squares } \\ \text { SV } & \text { Source of variation } & \text { TS } & \text { Total solid } \\ \text { TVFA } & \text { Total volatile fatty acids } & \text { VFA } & \text { Volatile fatty acids } \\ \text { VS } & \text { Volatile solid } & & \end{array}$

\section{Conflicts of Interest}

The authors declare no conflicts of interest

\section{References}

1. Benemann, J. Hydrogen biotechnology: Progress and prospects. Nat. Biotechnol. 1996, 14, 1101-1103.

2. Bockris, J.O.M. The economics of hydrogen as a fuel. Int. J. Hydrog. Energy 1981, 6, 223-241.

3. Mormirlan, M.; Veziroglu, T.N. Current status of hydrogen energy. Renew. Sustain. Energy Rev. 2002, 6, 141-179.

4. Ros, M.; Franke-Whittle, I.H.; Morales, A.B.; Insam, H.; Ayuso, M.; Pascual, J.A. Archael community dynamics and abiotic characteristics in a mesophilic anaerobic co-digestion process treating fruit and vegetable processing waste sludge with chopped fresh artichoke waste. Bioresour. Technol. 2013, 136, 1-7.

5. Ueno, Y.; Haruta, S.; Ishii, M.; Igarashi, Y. Microbial community in anaerobic hydrogen-producing microflora enriched from sludge compost. Appl. Microbiol. Biotechnol. 2001, 57, 555-562.

6. Kapdan, I.K.; Kargi, F. Biohydrogen production from waste materialk. Enzyme Microb. Technol. 2006, 38, 569-582. 
7. Levin, D.B.; Chahine, R. Challenges for renewable hydrogen production processes. Int. J. Hydrog. Energy 2008, 33, 279-286.

8. Westermann, P.; Jørgensen, B.; Lange, L.; Ahring, B.K.; Christensen, C.H. Maximizing renewable hydrogen production from biomass in a bio/catalytic refinery. Int. J. Hydrog. Energy 2007, 32, 4135-4141.

9. Nandi, R.; Sengupta, S. Microbial production of hydrogen: An Overview. Crit. Rev. Microbiol. 1998, 24, 61-84.

10. Nursten, H.E.; Williams, A.A. Fruit aromas: A survey of compounds identified. Chem. Ind. 1967, 486-497.

11. Winniczuk, P.P.; Parish, M.E. Minimum inhibitory concentrations of antimicrobials against micro-organisms related to citrus juice. Food Microbiol. 1997, 14, 373-381.

12. Jordan, M.J.; Tandon, K.; Shaw, P.E.; Goodner, K.I. Aromatic profile aqueous banana essence and banana fruit by gas-chromatography-mass spectrometry (GC-MS) and gas-chromatographyolfactometry. J. Agric. Food Chem. 2001, 49, 4813-4817.

13. Nogueira, J.M.F.; Fernandes, P.J.P.; Nascimento, A.M.D.C. Composition of volatiles of banana cultivars from Madeira island. Phytochem. Anal. 2003, 14, 82-90.

14. Rizzolo, J.; Polesello, A.; Teleky-Vamossy, G. CGC/Sensory analysis of volatile compounds developed from ripening apple fruit. J. High Resolut. Chrom. 1989, 12, 824-827.

15. Holland, D.; Larkov, O.; Bar-Yaákov, I.; Bar, E.; Zax, A.; Brandeis, E. Developmental and varietal differences in volatile ester formation and acetyl-CoA: Alcohol acetyl transferase activities in apple (Malus domestica Borkh.) fruit. J. Agric. Food Chem. 2005, 53, 7198-7203.

16. Tsanova-Savova, S.; Fany, R.; Maria, G. (+)- Catechin and (-) Epicatechin in Bulgarian Fruits. J. Food Comp. Anal. 2005, 18, 691-698.

17. Schieber, A.; Petra, K.; Reinhold, C. Determination of phenolic acids and flavonoids of apple and pear by high-performance liquid chromatography. J. Chromatogr. 2000, 910, 265-273.

18. Dieguez, S.C.; Lois, L.C.; Gomez, E.F.; de Ia Pena, M.L.G. Aromatic composition of the Vitis vinifera grape Albariño. Lebensm. Wiss. Und. Technol. 2003, 36, 585-590.

19. Aubert, C.; Baumann, S.; Arguel, H. Optimisation of the analysis of flavour volatile compounds by liquid-liquid microextraction (LLME). Apllication to the aroma analysis of melons, peaches, grapes, strawberries, and tomatoes. J. Agric. Food Chem. 2005, 53, 8881-8895.

20. Perry, P.L.; Wang, Y.; Lin, J.M. Analysis of honeydew melon (Cucumis melo var. Inodorus) flavor and GC/MS identification of (E,Z)-2,6-nonadienyl acetate. Flav. Frag. J. 2009, 24, 341-347.

21. Portnoy, V.; Benyamini, Y.; Bar, E. The molecular and biochemical basis for varietal variation in sesquiterpene content in melon (Cucumis melo L.) rinds. Plant Mol. Biol. 2008, 66, 647-661.

22. Aubert, C.; Pitrat, M. Volatile compounds in the skin and pulp of Queen Anne's pocket melon. J. Agric. Food Chem. 2006, 54, 8177-8182.

23. Hui, Y.H. Handbook of Fruit and Vegetable Flavours; John Wiley \& Sons: Hoboken, NJ, USA, 2010.

24. Utama, I.; Made, S.; Wills, R.B.H.; Ben-yehoshua, S.; Kuek, C. In vitro efficacy of plant volatiles for inhibiting the growth of fruit and vegetable decay microorganisms J. Agric. Food Chem. 2002, 50, 6371-6377. 
25. Grohmann, K.; Baldwin, E.; Buslig, B. Production of ethanol from enzymatically hydrolyzed orange peel by the yeast Saccharomyces cerevisiae. Appl. Biochem. Biotechnol. 1994, 45-46, 315-327.

26. Mizuki, E.; Akao, T.; Saruwatari, T. Inhibitory effect of citrus Unshu peel om anaerobic digestion. Biol. Wastes 1990, 33, 161-168.

27. Martin, M.A.; Siles, J.A.; China, A.F.; Martin, A. Biomethanization of orange peel waste. Bioresour. Technol. 2010, 101, 8993-8999.

28. Youngsukkasem, S.; Akinbomi, J.; Rakshit, S.; Taherzadeh, M.J. Biogas production by encased bacteria in synthetic membranes: Protective effects in toxic media and high loading rates. Environ. Technol. 2013, 34, 2077-2084.

29. Wikandari, R.; Youngsukkasem, S.; Millati, R.; Taherzadeh, M.J. Performance of semi-continuous membrane bioreactors in biogas production from toxic feedstock containing D-limonene. Bioresour. Technol. 2014, 170, 350-355.

30. Pan, J.; Zhang, R.; el-Mashad, H.M.; Sun, H.; Yimg, Y. Effect of food to microorganism ratio on biohydrogen production from food waste via anaerobic fermentation. Int. J. Hydrog. Energy 2008, 33, 6968-6975.

31. Liu, D.; Zeng, R.J.; Angelidaki, I. Hydrogen and methane production from household solid waste in the two-stage fermentation process. Water Res. 2006, 40, 2230-2236.

32. Kim, S.H.; Han, S.K.; Shin, H.S. Optimization of continuous hydrogen fermentation of food waste as a function of solids retention time independent of hydraulic retention time. Process Biochem. 2008, 43, 213-218.

33. Chu, C.F.; Xu, K.Q.; Li, Y.Y.; Inamori, Y. Hydrogen and methane potential based on the nature of food waste materials in a two-stage thermophilic fermentation process. Int. J. Hydrog. Energy 2012, 37, 10611-10618.

34. Lin, C.; Lay, C. A nutrient formulation for fermentative hydrogen production using anaerobic sewage sludge microflora. Int. J. Hydrog. Energy 2005, 30, 285-292.

35. Demirel, B.; Scherer, P. Trace element requirements of agricultural biogas digesters during biological conversion of renewable biomass to methane. Biomass Bioenergy 2011, 35, 992-998.

36. Demirel, B.; Scherer, P. Production of methane from sugar beet sludge without manure addition by a single stage anaerobic digestion process. Biomass Bioenergy 2008, 32, 203-209.

37. Pobeheim, H.; Munk, B.; Johansson, J.; Guebitz, G.M. Influence of trace elements on methane formation from a synthetic model substrate for maize silage. Bioresour. Technol. 2010, 101, 836-839.

38. Thauer, R.K.; Jungermann, K.; Decker, K. Energy conservation in chemotrophic anaerobic bacteria. Microbiol.Mol. Biol. Rev. 1977, 41, 100-180.

39. Dohanyos, M.; Kosova, B.; Zabranska, J.; Grau, P. Production and utilization of volatile fatty acids in various types of anaerobic reactors. Water Sci. Technol. 1985, 17, 191-205.

40. Vardar, S.G.; Maeda, T.; Wood, T.K. Metabolically engineered bacteria for producing hydrogen via fermentation. Microb. Biotechnol. 2008, 1, 107-125.

41. Thauer, R.K. Limitation of microbial $\mathrm{H}_{2}$-formation via fermentation In Microbial Energy Conversion; Schlegel, H.G., Barnea, J., Eds.; Pergamon Press: New York, NY, USA, 1977. 
42. Hawkes, F.R.; Hussy, I.; Kyazze, G.; Dinsdale, R.; Hawkes, D.L. Continuous dark fermentative hydrogen production by mesophilic microflora: Principles and progress. Int. J. Hydrog. Energy 2007, 32, 172-184.

43. Hawkes, F.R.; Dinsdale, R.; Hawkes, D.L.; Hussy, I. Sustainable fermentative hydrogen production: Challenges for process optimisation. Int. J. Hydrog. Energy 2002, 27, 1339-1347.

44. Ren, N.; Li, J.; Li, B.; Wang, Y.; Liu, S. Biohydrogen production from molasses by anaerobic fermentation with a pilot-scale bioreactor system. Int. J. Hydrog. Energy 2006, 31, 2147-2157.

45. Buyukkamaci, N.; Filibeli, A. Volatile fatty acid formation in an anaerobic hybrid reactor. Process Biochem. 2004, 39, 1491-1494.

46. Hallenbeck, P.C.; Benemann, J.R. Biological hydrogen production: Fundamentals and limiting processes. Int. J. Hydrog. Energy 2002, 27, 1185-1193.

47. Levin, D.B.; Pitt, L.; Love, M. Biohydrogen production: Prospects and limitations to practical application. Int. J. Hydrog. Energy 2004, 29, 173-185.

48. Polprasert, C. Organic Waste Recycling: Technology and Management; John Wiley \& Sons: Chichester, UK, 1996.

49. American Public Health Association Inc. (APHA). Standard Methods for the Examination of Water and Wastewater, 20th ed.; APHA: Washington, DC, USA, 1998.

50. USDA National Nutrient Database for Standard Reference, Release 27; US Department of Agriculture, Agricultural Research Service, Nutrient Data Laboratory, Beltsville, MD, USA, August 2014.

(C) 2015 by the authors; licensee MDPI, Basel, Switzerland. This article is an open access article distributed under the terms and conditions of the Creative Commons Attribution license (http://creativecommons.org/licenses/by/4.0/). 